\title{
FEMINIZATION OF TEACHING
}

\author{
- Yayan Rahayani \\ Sarjanawiyata Tamansiswa University
}

\begin{abstract}
We are turning a familiar fact into a feminization of teaching. How and why school teaching has shifted from a predominantly male to a female occupation, and why males handle the top managerial at school and leaves female keeps their position as classroom teacher. Feminization of teaching in one side provides opportunity for women to take part in public sphere, especially as the increasing demand of teacher for the compulsory program. On the other hand, it seems that feminization of teaching is merely seen as the extension of family matters, which are closely related to mothering and nurturing. Consequently, feminization projects another form of domestication for women. Sadly, this condition has been supported by the fact that women rarely get access to managerial position within the educational institution. This paper will discuss the feminization of teaching in general context.
\end{abstract}

Keywords: feminization, public sphere, domestic sphere, domestication.

\section{Introduction}

Teaching is a good job for a woman, bit it is a career with prospects for men. (Burgess, 1989)

In occupational studies, feminization refers to "a process in which the number of women in an occupation increases until the occupation switches from being predominantly male to predominantly female" (Reskin and Ross, 1990, cited in Addi-Reccah, 202, p. 231). It can be seen that women's participation in the labour force increase significantly. Wylie (2000) argues that feminization always correlates with "a statistical meaning, used in calculating percentages of men and women in a given profession." Other different definition of feminization refers to gender balance that includes positional, policy, and organizational balances (Martin, 2000, p. 169; and see also Lovenduski, 1996). Positional means "the numbers of men and women in organizations as a whole end, and, within those organizations, to their presence in decision-making positions" (cited in Griffiths, 2006, p. 399). Griffiths (2006) adds that policy refers to "the extent to which public 
policies impact on women and men in somewhat different ways; as well as the question of who plays the majority role in the policy-making process". The last term reflects "the biases integral to the rules, values, norms, structures and policies of a specific organization", (cited in Griffiths, 2006, p. 399).

On the other hand, Strober (1988) argues that men tend to leave one type of occupation in order to find other more lucrative job (Addi-Reccah, 202, p. 231). When the labour market condition empty, then, women will take the related opportunity. The sexual division of labour is one of the most enduring and universal characteristics of work (Blau, 1984a; Brown, 1998; Tallerico and Blount, 2004). It can be found in both unpaid and paid employment (Beneria, 1988; Middleton, 1988) as well as in education and other fields of occupation (Brustyn, 1980; Schwartz, 1992). The segregation of occupation divides into men and women. So, there are domestic and public spheres. Women-refer to the first category, which is domestic workforce while men predominantly work outside the home (Bloch, 1978; Welter, 1966). Historically, from the late $19^{\text {th }}$ to early $20^{\text {th }}$ centuries, some types of occupation, such as secretarial work, bank telling, and school teaching move from exclusively male into predominantly female occupations (Blount, 1998; Davies, 1982; Reskin and Ross, 1990; strobe, 1984).

In the nineteenth century, industrial society tries to achieve independence, economic self sufficiency and political cohesion. As a result, women at that time played an important role in term of spreading and developing of universal schooling because of some reasons (Kyle, 1988, p. 26). Firstly, women reflect the cheap labour. Other reason is that a common belief that the teaching of young children was simply an extension of women's mothering role. Prentice and Theobald (1991) pointed out that there were some literatures of nineteenth century, which reflects studies on feminization of teaching. Feminization of teaching occurs in many countries (Spencer, 1997). Socio-cultural and economic factors give significant influence toward that movement (Acker, 1995; Theobald, 1991). At the first time, women entered gradually into primary school and followed by the next higher level, such as secondary (Spencer, 1997). Thus, the question of this essay is whether feminization of teaching can be seen as an opportunity for women or it reflects another form of domestication for women? In my opinion, schools would benefit from having both men and women in all their cultural diversities. Insofar, teaching as profession should be able to create a culture that values difference.

This essay begins with introduction that explains the definition of feminization of teaching and its historical background. The next section will explain a brief history of employment. Then, it is followed by a discussion whether 
the participation of women in teaching can be regarded as private or public sphere. The last will be an explanation of gender and teacher's career, and conclusion part follows at the end.

\section{History of Employment}

In the past decades, there was a rapid change in employment trends among teachers in many countries. During the 1970 s teacher employment stagnated in general, then, followed rapid expansion in this field of occupation. In other word, the number of teachers employed continues to increase in some countries. This trend has been labelled as an "excess" of teachers (ILO, p. 5). The growth of teacher employment in primary level might be because of the basic compulsory education. So, this primary level of schooling needs more women as it is identical with the extension of extended family. However, Wylie (2000) argues that "the teaching profession is not alone in experiencing growing proportions of women as paid employment becomes the norm for most women, and their qualification level has increased." She adds that other social service industries and service roles which include women even relatively in small proportion; they have also experiencing feminization process over the last 20 years (cited in Griffiths, 2006, p. 400).

There are some reasons behind the increased number of women participation in the labour force (Harvey, 1978, p. 40). Firstly, the important of family and career in women's personal values (Fogarty, Rapoport and Rapoport, 1971). Both "traditional" and "contemporary" values reflect women's perception toward career and family (Lipman-Bluman, 1972, p. 34-42). Women with traditional value view their main responsibility as home maker and child minder. Thus, women in this group perceive that career is not as important as their family. By contrast, women with contemporary understanding need self actualization through career. As a result, women's personal value system is an important factor in the decision of entering the work force. Secondly, educational level can also be considered as one of significant factor in women's participation in labour force (Richmond, 1974, p. 281-289). As Harvey (1978) argues that "women with higher levels of education are not only more likely to be in the workforce than less well- educated women, but they also appear to be likely employed in more rewarding, better paid and more permanent occupations" (p. 44). Lastly, the structure of labour market affects women participation in to the workforce. 


\section{Women teachers' work: domestic or public sphere?}

The term "public role" or "public sphere" is usually contrasted with "domestic role" or "domestic sphere". The first term is associated with men's sphere of influence and related to the work place; while the second is related to women's world or the household (Amstrong, 2000, in Kramarae and Spender (eds.), p. 2137).

In discussing the participation of women teachers, it is crucial to acknowledge the position of women in society (Deem, 1978, p.135). In the past, particularly women in industrial society were regarded as an isolated character of labour. Women depended their economic on men as the main breadwinners and it was the stereotype at that time. After that there was a decline in number of women dependency in term of economy. As a result women tried to enter the labour force even though only in domestic labour and child care (at the early stage). In this phase, the subordination and oppression towards women still exist. However, there are some changes in the division of labour nowadays. Women get better position. They not only can participate in domestic sphere, but also in some sectors that belong to public sphere.

The participation of women teachers in the private sphere in the nineteenth century was misnomer. It was because of historian only looked at the rise of statesponsored systems of schooling (Prentice and Theobald, 1991, p.16). Women teachers who entered this sphere had suffered the common economic fate in the past (Pedersen, 1975). Theobald in her article Mere Accomplishments argues that the feminization of teaching is "a victim of male/ bureaucratic definitions of education and professionalism"' (cited in Prentice and Theobald, 1991, p. 17). She believes that women can create and sustain a tradition of female 'accomplishment' in educational field. It is a good process because this situation encourage women teacher to be professional in their works. Based on her finding, women teachers in the nineteenth century were committed to be professional in their own sphere of excellence.

Women teaching in public sphere arise as the influence of the transformation of teaching into women's work, especially in America (Clifford, cited in Prentice and Theobald, 1991, p. 18). Clifford's study found that there was a reality of women who were becoming teachers although they were not paid by the state as workers. Women participation in teaching which is regarded as public sphere began in the early twentieth century. At this stage, women demonstrate their commitment toward teaching. This condition also illustrates those women teachers "struggled to improve their working lives, many continued to live and work in 
worlds that were isolated and even threatening" (Prentice and Theobald, 1991, p. 21).

The thing that worries me is if the feminization of teaching was categorized as a domestic sphere, it would give some bad implications for women. For example, if teaching is predominantly by women, this condition leads women teachers to domesticate themselves through which they are isolated from men's world. I assume that the great involvement of women in teaching could be the reason of combining both family and work at the same time as above (traditional view). In regard to private sphere, it will be better for women teachers if they can teach not only in primary level of private and state-sponsored schools, but they can take part in all levels and all different types of schooling. In my view, women teachers should also have a good career path as men do. It does not only allow them to spend their lifetime in classroom, but to bring them into administrative and leadership level. Thus, the equality between men and women teachers leads to the reduction of women subordination and oppression. In short, this essay simply states that women participation in teaching should be regarded as public sphere rather than the domestic in term of avoiding of "keeping women teachers in their 'proper place' unrewarded and unpromoted" (Kyle, 1988, p. 25).

\section{Gender and Teacher's Career}

The data from the last decades indicates that economic and social transformation accompanied the feminization of teaching (Wallace, 1996, p.46). Additionally, Cott explains that the period between 1780 and 1830 was the time for transformation which known as the start of rapid economic growth, such as foreign commerce, agricultural productivity, and so forth; the beginning of urbanization; democratization in politics; and as the emergence of the domesticity of family life (Wallace, 1996, p.45). A precondition of feminization of teaching force appeared with expansion of educational opportunity for girls after the American Revolution (Strober and Tyack, 1980). In this stage, women began to teach. For instance, in Massachusetts the feminization of teaching was usually associated with the urbanization and industrialism, particularly amongst the wealthier communities (Kaestle and Vinovskis, 1980). The increased participation of women in teaching in the related area can exist because men could find alternative better employment with higher salaries. Thus, this condition forced the school board to hire women teachers.

There are some types of sex- labelled occupation and one of them is teaching. Teaching is sex-labelled as female occupation (Harvey, 1978, p. 58). He 
argues that teaching, especially in primary level has become female domain in Australia and other countries. The tendency of increased female proportion in teaching has become evident since 1950. Thus, a gendered division of labour exists with the teaching profession (Acker, 1994). Basically, both men and women can get equal opportunity in teaching as career (Measor and Sikes, 1992, p. 111.) However, "the traditional sex segregation has been maintained by processes of exclusion, discrimination and differential allocation of status within occupation" (Harvey, 1978, p. 61).

From professionalization point of view, it is necessary to draw the characteristics of teacher in discussing the career of teachers. The main characteristic of teacher as a profession is in term of giving services rather than the self interest of its practitioner (Lieberman, 1960, p. 214-215). Since the teaching is not highly paid employment, then, people see it as an altruistic motive. Other key factor of teaching is having a deep interest in children. This characteristic is debatable. Other research finding said that the most important thing to be a teacher is characterized by a strong interest in helping others (Lieberman, 1960, p. 221).

Since the emergence of feminization of teaching, the profession of teaching, particularly in elementary level has been closely associated with the notions of nurturance and care while in the secondary as intellectual work (Whitehead, 2000, p. 2). Other researcher also identified that the involvement of women in teaching is close to the "nurturance, empowerment of learners, and tolerance of difference, as well as an ethic of forbearance and patience" (Sharoon, 2001 , p. 3). Unfortunately, the highest proportion of women exists in the elementary level. It seems that teaching in primary can be seen as an extension of family. The Junior Secondary Review (JSR) reflects that even though women teachers dominated in number, but mostly they spent their career as classroom teachers while men in administration level (Whitehead, 2000). Wallace (1996) stated that many women assumed that teaching as "mission of republican of motherhood" within the family and they have extra role in the more public realm, which is school (p. 53). On the other hand, principally, teachers have great roles since they can be "gate keepers in its traditions and culture, and also facilitators of its evolution" (General Teaching Council Trust, 1993, cited in Bottery and Wright, 2000 , p.68). Because teachers can contribute to students' emotional, social and moral development as well as stimulate their minds, and improve them with skills for the sake of their own, and community needs.

There are some studies that have provided information on teachers' career progression. For example, NUT and Amma (1980 and 1985) explored the experience of women teaching; DFE (1991) shows that the recent statistics data 
implies that teaching is becoming increasingly feminized profession; School Teachers' Review Body STRB (1994) gives projections that teacher demand and supply new. entrants will continue to be outnumbered until 1996 (Geraldine and David, 1994). However, Geraldine and David (1994) argue that the finding gives negative impact upon the professional status of the teachers, their job satisfaction, and their status. It seems that likely the negative impact emerges because of the increasing feminization of the teaching profession brings women teachers to be disadvantages than male teachers. The research suggests that the government should give more emphasis on rewarding process of teacher performance, which is in line with the move of teaching as occupation from the private to the public workforce. This essay argues that the reward is not only in better payment, but also in giving opportunity for women teacher to get equal career paths in term of promotion.

Promotion process can take place both in formal and informal (Coffey and Delamont, 2000 , p. 51). In tem of formal promotion, it is difficult to identify a discrimination against women because it is monitored by a specific legislation on gender equality in employment. For instance, in the UK, there is the UK sex Discrimination Act 1975). Informal aspects of promotion process can be seen in the role of networks, sponsors, role models, and general encouragement (Evetts, 1990; Bloot and Browne, 1996).

In addition to that, in term of promotion, women tend to focus more on promoted posts that are "mainly pastoral in nature" (Torrington and Weightman, 1989, cited in Coffey and Delamont, 2000, p. 47). In other word, women teachers who are promoted into principalship, they prefer to get posts that are likely related to pastoral care. For instance, the involvement of teachers in primary level tends to reflect the notion of post, which can combine teaching and caring role (Mercer, 1997). It means that in school level, women teachers' career clustered in lower position and less promoted. Generally in educational level, Coffey and Delamont (2000) argue that "women are under-represented in headships, senior teacher roles, educational leadership and administration" (p. 45). For example, Taylor's (1995) finding explains that in Canada, three-quarters of elementary school teachers are women and three quarters of the principals are men while in the secondary level half of teachers in this level are women, but more than $85 \%$ of school principals of secondary schooling are men (p. 123-42). Thus, even though the number of women participation in teaching has increased significantly, but the number of female principals in this work force does not mirror this. Generally, Women are less likely than men to have control over their work, to direct the work of others, or to have opportunities for promotion (Kramae and Spender, 2000, p. 2132). It seems that 
this situation can be applied to all types of occupation, which are entered by women, not only in educational institutions. In respond to this situation, the problem seems that women tend to ignore the opportunities and they. lacks of information (Coffey and Delamont, 2000, p. 47, see also Henwood, 1996).

Those factors can represent the three big issues in the notion of under representation of women teachers. First of all is the question of women teachers' commitment and career advancement. Secondly, there is an assumption that the promotion process belongs to male mainstream. Lastly, school management has been perceived as based on male models of leadership and discipline.

However, women teachers have been actively get involved in teacher unions as they seen it as a way of challenge male hierarchies (Rowbotham, 1989; Weiner, 1994). But, the notions of equal payment and equal status are still becoming big issues within teacher unions as the teacher unions "have not provided an alternative source of career advancement and job satisfaction for women teachers (Coffey and Delamont, 2000, p. 48-49). The issue of unequal payment toward women teacher is similar with the notion of cheap labour. Theobald (1996) pointed out that since the beginning of the participation of women in teaching; they are regarded as cheap labour. Unfortunately, there is only little explanation on the discourse of women teacher.

\section{Conclusion}

In short, "while teaching becoming increasingly feminized (in term of number), it is not becoming distinctly feminist (in term of career trajectories, discourse and ethos) as long as teaching is being conceptualized as semiprofession (Coffey and Delamont, 2000, p. 48). As consequences, women teachers are still regarded as cheap labour and less promoted. This condition implies that men teachers were central in service ladders and their career paths were protected by system that did not include women from leadership. In contrast, women teachers mostly spent their career as classroom teachers. Theobald (1996) argucs that women seldom become heads of any schools but it is possible for women in the smallest country schools where no man could be found to take the position. It is clear that gender relations really have significant influence in constructing the image of women teachers. It seems that gender orders seriously drive and locate women mainly in domestic sphere.

As a result of an increased feminization of teaching, it seems that government in some countries try to bridge the gap of gender relations in this profession by reorganization of teaching, such as managerialism (Amot and Miles, 
2005). In fact, this process tends to recruit more male into teaching profession. In other word, government tries to masculinise the teaching profession. I tend to agree in regard to the government effort to attract more male into teaching, but not in the discourse of creating a masculinisation of teaching because schools will get some benefits from having both men and women in all their culture diversities.

Lastly, even though feminization of teaching can be seen as a domestication process for women, but it can also be seen as an opportunity because this process gives women chance to move forward from "real" domestic to semi public sphere. Therefore, the involvement of females in this labour force is not rewarded by better consequences as male counterparts (e. g. career path).additionally, ILO portrays that there some other benefits for women from the increased of feminization in teaching;

"It would appear that increased levels of feminization pave the way for a decrease in horizontal segregation, allowing a higher proportion of women to become head teachers. This is not a mechanical relation, but differs from country to country, and takes time to show itself. Other changes in the role of the head teacher may also be playing a part."

(Wylie, 2000).

I believe that the excess proportion of female participation in teaching will have long term effect on the practices of teaching in term of its benefits. Thus, feminization of teaching is far from being threat to good schooling, it is an opportunity to improve education for both sexes.

\section{References}

Acker, S. (1994). Gendered Education: Sociological reflections on women, teaching, and feminism. Buckingham: Open University Press.

Addi-Raccah, A. (2002). The feminization of teaching and principalship in the Israeli educational system: A comparative study. Sociology of Education. Academic Research Library. 75:3.

Alexander, J. (1998). Civil Society between Difference and Solidarity: Rethinking Integration in the Fragmented Public Sphere. Theoria.

AMMA. (1985). Women teachers career prospects1985. Assistant Masters and Mistresses Assiciation.

Arnot, M., \& Miles, p. (2005). A reconstruction of the gender agenda: The contradictory gender dimensions in New Labour's educational and 
economic policy. Oxford Review of Education. Vol. 31. No. 1. retrieved from Ingenta Content Distribution-Routledge.

Bloot, R., \& Browne, J. (1996). Reasons for the underrepresentation of females at head of department level in physical education in government schools in Western Australia. Gender and Education. 8.1.

Bottery, M., \& Wright, N. (2000). Teachers and the state: Towards a directed profession. London: Routledge.

Coffey, A., \& Delamont, S. (2000). Feminism and the classroom teacher: Research, praxis and pedagogy. London: RoutledgeFalmer.

Deem, R. (1978). Women and schooling. London: Routledge \& Kegan Paul.

Fraser, N. (1992). Rethinking the Public Sphere: A Contribution to the Critique of Actually Existing Democracy. Habermas and the Public Sphere. Craig Calhoun (ed.). Cambridge: MIT press.

Geraldine, H., \& David, K. ( 1994). Gender and change: The case of teaching. Management Research News.Patrington. Vol. 17. Iss. 7, 8, 9. Retrieved from http://proquest.umi.com/

Griffiths, M. (2006). The feminization of teaching and the practice of teaching: Threat or opportunity?. Educational Theory. Vol. 56. no. 4. retrieved from ProQuest Education Journals.

Henwood, F. (1996). WISE choices? Understanding occupational decisionmaking in a climate of equal opportunities for women in science and technology. Gender and Education. 8. 2.

ILO. (1981). Employment and conditions of work of teachers. Geneva: International Labour Office.

Kaestle, C., \& Vinovskis. M. (1980). Education and social change in nineteenth century Massachusetts. New York: Cambridge University Press.

Kramarae, C., \& Spender, D. (2000). Routledge International encyclopedia of Women: Global Issues and knowledge, London: Routledge.

Kyle, N. (1988). Women's natural mission' but man's real domain: The masculinisation of the state elementary teaching service in the New South Wales. In Miriam Henry and Sandra Taylor. (eds.). (1989). Battlers and Bluestockings: Women's place in Australian education. Canberra: Australian College of Education. 
Lieberman, M. (1960). Education as profession. Englewood N. J: Prentice-Hall, Inc.

Lovenduski, J. (1996). Sex, gender and British politics. Joni Lovenduski and Pippa Norris (eds). Women in Politics. Oxford: Oxford University Press.

Martin, J. (2000). To blaise the trail for women to follow along: Sex, gender and the politics of education on the London school board, 1870-1904. Gender and Education 12. no. 2 .

Measor, L., \& Sikes, P. (1992). Gender and School. London: Cassell.

Mercer, G. (1997). 'Feminist pedagogy to the letter: a musing on contradictions.' In L. Stanley (ed.). Knowing feminism: On academic borders, territories, and tribes. London: Sage.

National Union of Teachers (NUT), and Equal Opportunities Commission (EOC). (1980). Promotion and the women teacher. London.

Prentice, A., \& Theobald, M. R. (1991). Women who taught: Perspectives on the historyof women and teaching. Totonto: University of Toronto Press.

Reskin, B. F., \& Roos, P. A. (1990). Job queues, gender queues: Explaining women's inroad into male occupation. Philadelphia: Temple University Press.

Rowbotham, S. (1989). The past is before us: Feminism in action since the 1960s. London: Pandora.

Sharoon, A. C. (2001). A case study of equity program in teacher education: Rethinking feminist leadership. Canadian Journal of Education. Vol. 26. Iss. 3. Toronto. Retrieved from http://proquest.umi.com/

Strober, M. (1988). The process of occupational segregation: Relative attractiveness and patriarchy. Annual meeting of American Educational Research Association and International Conference on Private WomenPublic Work.

Strober, M. H., \& Tyack. D. (1980). Identify “preconditions" and "precipitants" for feminization in "why do women teach and mn manage: A report on research on schools. Signs: Journal of women in culture and society. 5.

Taylor, A. (1995). Glass ceilings and stone walls: Employment equity for women in Ontario school boards. Gender and Education. 7.2.

Torrington, O., \& Weightman, J. (1989). The reality of school management. Oxford: Blackwell. 
Theobald, M. R. (1985). "Mere accomplishments"? Melbourne's early ladies's schools reconsidered, reprinted in "Julie Vieusseux: The lady principal and her school in Marilyn Lake and Farley Kelly, eds. (1985). Double Time: Women in Victoria 150 Years. Mclbourne: Penguin.

Theobald, M. R. (1996). Knowing women. Hongkong: Cambridge University Press.

Wallace, J. M. (1996). The feminization of teaching in Massachusetts: A reconsideration. Women of the commonwealth: Work, family, and social change in the nineteenth-century Massachusetts. Potter, L. S. (ed.). The USA: The University of Massachusetts Press.

Weiner, G. (ed.). (1994). Feminism in education: An introduction. Milton Keynes: Open University Press.

Whitehead, K. (2000). Teachers, gender and the report of the Junior Secondary . Review. Joturnal of Educational Enquiry. Vol. 1. No. 1. Australia: Flinders University of South Australia.

Wylie,' C. (2000). Trends in feminization of the teaching profession in OECD countries 1980- 1995. Geneva: International Labour Office. Retrieved from http:/www.ilo.org/public/english/dialogue/sector/papers/feminize/wp151.htm. 